\title{
Effect of ginger extract and sugar level in the sensorial quality and acceptability of Sinaging processed from swamp taro (Cyrtosperma chamissonis)
}

\section{Melogen B. Bandalan', Clarita E. Morbos ${ }^{2 *}$, Jenalyn M. Gonzaga ${ }^{3}$, Eliza C. Cabugawan $^{3}$ and Amalia Paraluman B. Lombrio ${ }^{3}$}

This study aimed to evaluate the sensory quality and acceptability of Sinaging as affected by the different levels of ginger extract and calamay sugar, obtain the optimum combination of ginger extract and calamay sugar, and determine the cost of producing Sinaging. A $3 \times 3$ Full Factorial experiment in Completely Randomized Design was employed. Three levels of ginger extract $(2,4,6 \% \mathrm{w} / \mathrm{w})$ and sugar levels $(20,25,30 \% \mathrm{w} / \mathrm{w})$ were the variables considered. Sensory evaluation using quality scoring in combination with the 9-point Hedonic scale was carried out. The results were subjected to statistical analysis using Statistica 8.0 software and Statistical Analytical Software version 9 (SAS 2008).

Results revealed that the different levels of sugar and ginger extract significantly affected linearly the flavor, taste, and general acceptability of Sinaging. No significant effect was observed on its color, aroma, texture, and aftertaste. The mean acceptability rating of the different treatments ranged from 7.15 to 7.41 which corresponds to 'like moderately' in the 9-point Hedonic scale. The optimum combination was at $4.05 \%$ and $28.75 \%$ ginger extract and sugar, respectively. The production cost of the optimum formulation was 8.34 pesos per piece weighing $75 \mathrm{~g}$ of Sinaging.

Keywords: calamay sugar, food delicacies, sensory evaluation, Sinaging, Palawan rootcrop

\section{INTRODUCTION}

Processing and sale of food delicacies is an additional source of income for the local population in Eastern Samar, Philippines. Sinaging is one of the delicacies

\footnotetext{
${ }^{1,2,3}$ Eastern Samar State University - Salcedo Campus, Salcedo Eastern Samar, Philippines 
produced in the province, particularly in the municipality of Salcedo. It is made mainly from Palawan or swamp taro and other materials such as banana, rice, margarine butter, peanuts, and sugar. The mixture is wrapped in coconut leaves prior to boiling or cooking.

Swamp taro, which is locally known as Palawan, is a variety of Cyrtosperma chamissonis found in the swamp areas in the municipality of Guiuan, Eastern Samar and in its nearby municipalities including Salcedo. The edible portion of the Palawan contains carbohydrates, fats, fibers, calcium, iron, zinc, $\beta$ carotene, thiamine, and Vitamin C, and it is considered to be a high-energy giving food (Southernlan 1971) as cited by Pagatpatan et al (2017).

The main product of swamp taro is the corm that can be roasted, boiled, baked, mashed, grated, and combined with other starches. For low-income families in rural areas, Palawan is boiled, served, and eaten as substitute for rice (Pagatpatan et al 2017). It often appears on the menus of local community feasts or banquets in the province. In Salcedo, Palawan is also commonly grated and combined with other ingredients to produce the Sinaging delicacy.

Formulation optimization of food delicacies by considering the sensory quality and acceptability is important. Molded dark brown sugar locally known as Calamay and ginger are among the ingredients that have to be optimized after the preliminaries. Sugar constitutes a vital category of ingredients in the food industry and can be used as flavor enhancers (Galant 2015). Its brown color is due to the presence of molasses; thus, it contains some beneficial biofunctions such as antioxidant, cytroprotective, and antiangiogenesis activities (Asikin et al 2016). Ginger (Zingiber officinale Roscoe) is a plant that belongs to the Zingiberaceae family. The plant is indigenous to warm tropical climates. The Zingiberaceous plants have strong aromatic and medicinal properties and are characterized by their tuberous or non-tuberous rhizomes (Chen et al 2008) as cited by Islam et al (2014). Ginger is relatively inexpensive due to its easy availability, universal acceptability, and is well-tolerated by the most people (Islam et al 2014). Ginger products, such as essential oil and oleoresin, are internationally commercialized for use in food and pharmaceutical processing. The essential oils are composed of monoterpene hydrocarbons, sesquiterpene hydrocarbons, and oxygenated monoterpene. Although the latter has the least concentration, it is the major contributor to the taste and aroma of food substances (Parthasarathy et al 2008).

Optimizing the two variable ingredients, namely calamay sugar and ginger, would help the food processors improve the current Sinaging product in the locality. Hence, this study was conducted to evaluate the sensory quality and acceptability of Sinaging as affected by the different levels of ginger extract and calamay sugar; determine the optimum combination of ginger extract and calamay sugar in producing Sinaging; and determine the cost of producing this optimum Sinaging product.

\section{MATERIALS AND METHODS}

\section{Preparation of Ginger Extract}

The ginger, procured from the local market of Salcedo, was washed and sanitized by immersing the ginger in sodium hypochlorite solution (10-20ppm ) for 
5-10min. This was peeled and grated manually. The ginger extract was collected by using a cheesecloth and the liquid extract placed in a sterilized glass container.

\section{Processing of Sinaging}

Young coconut meat and cocomilk with different levels of molded brown sugar, locally known as Calamay, were cooked for $15 \mathrm{~min}$ on a medium heat. These were added to the mixture of grated Palawan and banana (Masbad variety). Other ingredients such as margarine butter, peanut, and the different levels of ginger extract were then added and mixed together. The Sinaging mixture was wrapped in coconut leaves and steamed for an hour.

\section{Experimental Design}

A 3x3 Full Factorial experiment in Completely Randomized Design with nine experimental treatments was used in the study. The variables considered were the different levels of ginger extract and sugar levels. Table 1 shows the experimental treatments.

Table 1. Experimental treatments of Sinaging with different levels of ginger extract and sugar levels

\begin{tabular}{|c|c|c|c|}
\hline Treatment & Ginger Extract & Levels (\% w/w) & $\begin{array}{c}\text { Sugar Levels } \\
(\% \mathrm{w} / \mathrm{w})\end{array}$ \\
\hline 1 & & 2 & 20 \\
\hline 2 & & 4 & 20 \\
\hline 3 & & 6 & 20 \\
\hline 4 & & 2 & 25 \\
\hline 5 & & 4 & 25 \\
\hline 6 & & 6 & 25 \\
\hline 7 & & 2 & 30 \\
\hline 8 & & 4 & 30 \\
\hline 9 & & 6 & 30 \\
\hline
\end{tabular}

\section{Sensory Evaluation}

Sensory evaluation using quality scoring in combination with 9-point Hedonic scale was carried out to evaluate the sensory attributes of the different treatments, which includes color, aroma, texture, taste, aftertaste, and general acceptability.

An Incomplete Block Design (IBD) as laid out by Cochran and Cox (1957) was used during the presentation of the different treatments, since nine treatments are too many for each panelist to evaluate. The set plan of $t=9, k=6, b=12, r=4, E=0.94$ Type II, was followed, where $\underline{t}$ refers to the number of treatments, $\underline{r}$ the number of replications based on the IBD, $\underline{b}$ the number of blocks, and $E$ the efficiency factor (Table 2).

The set plan was replicated four times to get 48 panelists with 32 panelists evaluating per treatment. Samples were served with randomly coded three-digit numbers and presented with the corresponding score sheet specific for each panelist. 
Effect of ginger extract and sugar level

Table 2. Type II Set Plan of Incomplete Block Design for Sensory Evaluation (Cochran and Cox 1957)

\begin{tabular}{cllllll}
\hline Block & I & II & III & IV & V & VI \\
\hline 1 & 1 & 2 & 4 & 5 & 7 & 8 \\
2 & 2 & 3 & 5 & 6 & 8 & 9 \\
3 & 1 & 3 & 4 & 6 & 7 & 9 \\
4 & 1 & 2 & 5 & 6 & 7 & 9 \\
5 & 1 & 3 & 4 & 5 & 8 & 9 \\
6 & 2 & 3 & 4 & 6 & 7 & 8 \\
7 & 1 & 3 & 5 & 6 & 7 & 8 \\
8 & 1 & 2 & 4 & 6 & 8 & 9 \\
9 & 2 & 3 & 4 & 6 & 8 & 9 \\
10 & 4 & 5 & 6 & 7 & 8 & 9 \\
11 & 1 & 2 & 3 & 4 & 5 & 6 \\
12 & 1 & 2 & 3 & 7 & 8 & 9 \\
\hline
\end{tabular}

$\mathrm{t}=9, \mathrm{k}=6, \mathrm{~b}=12, \mathrm{r}=4, \mathrm{E}=0.94$, Type II

\section{Statistical Analysis}

\section{Descriptive scoring}

The different descriptions of the product's sensory attributes were determined by getting the frequency based from the corresponding descriptive scores perceived by the panelists.

\section{Optimization Experiments}

The location of the optimum region was determined by superimposing the contour plots of the acceptability scores of all the sensory attributes being evaluated from the Sinaging. The contour plots were obtained using the mean values of the attributes tested. It gave an idea as to which levels ginger and sugar would result in a better-quality product. Results of the sensory evaluation were subjected to Response Surface Regression (RSREG) analysis using Statistical Analytical Software version 9 (SAS 2008) in the analysis of the sensory quality and acceptability for all formulations of the product. The Statistica 8.0 software was used for the graphical presentation of the response surface plots.

\section{Verification}

A verification experiment was conducted to verify the predictive ability of the model equations used to predict the sensory acceptability of Sinaging. The product was processed using the optimized formulation and subjected to sensory evaluation. A single sample t-test was used to check the difference between the observed means and predicted means of the sensory acceptability scores. Furthermore, the percent error and percent difference were calculated to check the accuracy and precision of the data gathered. 
To further verify that the Sinaging processed using the optimized formulation had a better and higher acceptability rating, a sample of the product which was processed using the formulation located outside the optimum region was rerun.

\section{Cost of Production}

The price of the ingredients and other expenses were based on the unit selling prices in a specific location where the product can be purchased. The total cost of the product was computed by adding all the expenses incurred. The contour plot of the cost was superimposed and was included in determining the optimum region.

\section{RESULTS AND DISCUSSIONS}

\section{Color}

The color of the different treatments of Sinaging ranged from yellowish brown to dark brown. The results revealed that the acceptability score ranges from 7.0 to 7.57 which was equivalent to 'like moderately' to 'like very much' of the 9-point Hedonic scale. The product had an average response mean of 7.41 which falls under 'like moderately' as presented in Table 3a. The varied color description of Sinaging was due to the varying levels of calamay sugar which has a natural dark brown color, and ginger with a yellowish color. Figure 1 shows the contour plot showing the trend in the color acceptability. However, this trend was not significant as presented in the results of the parameter estimates in Table 4. It reveals that the difference in the color acceptability among treatments was not significant as the calamay sugar and ginger levels varied. This indicates that a darker or lighter color of Sinaging would not affect the perception of the panelists in terms of the degree of likeness.

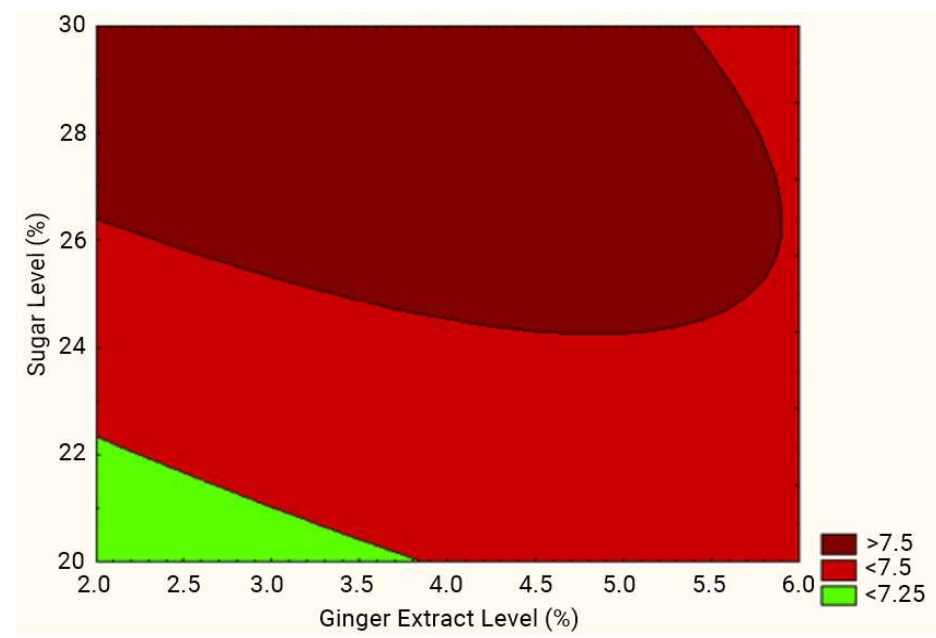

Figure 1. Contour plot of the color acceptability with varying levels of sugar $(\% \mathrm{~W} / \mathrm{w})$ and ginger extract $(\% \mathrm{w} / \mathrm{w})$ with an acceptability rating of $\geq 7.25$ 
Table 3a. Quality description and mean acceptability ratings of color, aroma, and flavor of Sinaging as affected by different levels of ginger extract (GL) and sugar level (SL).

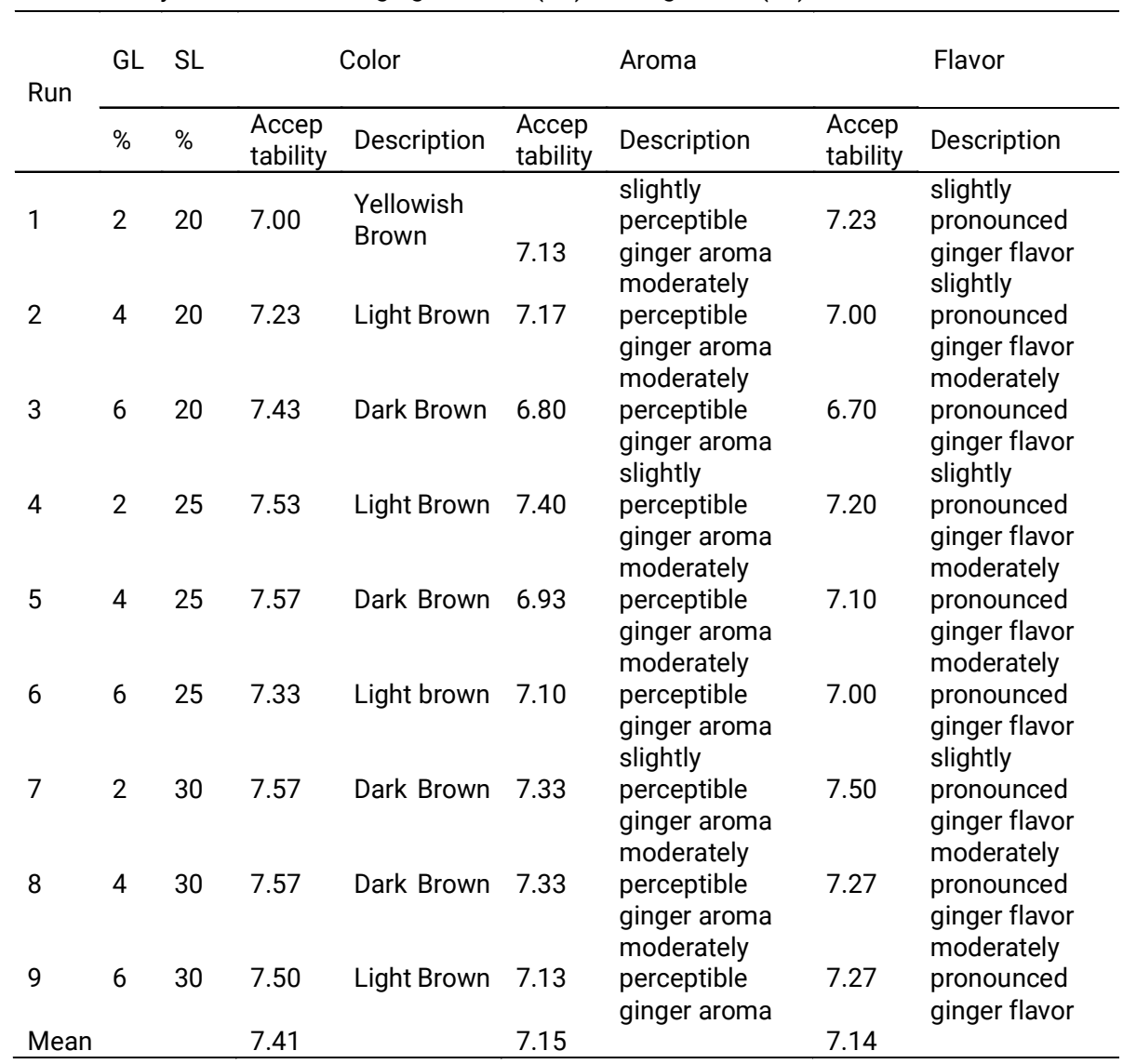

Legend: GL - Ginger Level, SL - Sugar Level

$\mathrm{N}=30$ panelists; Range of scores: 9 -like extremely;8-like very much;7-like moderately;6-like slightly;

5-neither like nor dislike,4-dislike slightly;3-dislike moderately;2-dislike very much;1-dislike extremely

\section{Aroma}

The aroma is an important consideration in determining product quality. The mean aroma acceptability of Sinaging is 7.15 which falls under "like moderately" in the 9-point Hedonic scale (Table 3a). The panelists perceived a 'slightly perceptible ginger aroma' to 'moderately perceptible ginger aroma'. Figure 2 shows the contour plot of the aroma acceptability. It can be noticed that close to the maximum levels ginger, there was a slight decrease in its acceptability. However, this decrease was not significant based from the parameter estimates in Table 4 . This means that both levels of ginger and calamay sugar could be raised or reduced without significantly affecting the acceptability of the aroma. 


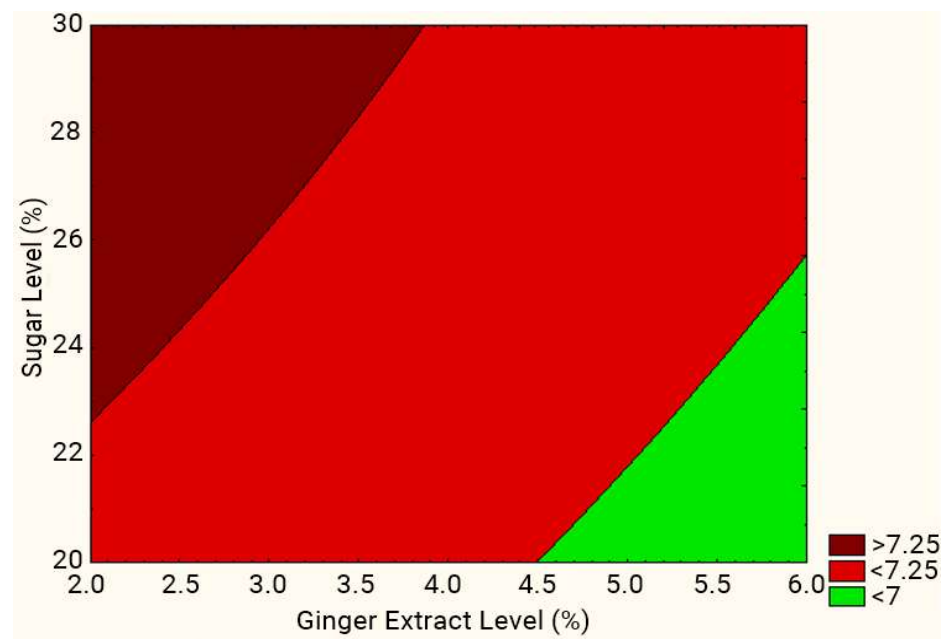

Figure 2. Contour plot of the aroma acceptability with varying levels of sugar $(\% \mathrm{w} / \mathrm{w})$ and ginger extract $(\% \mathrm{w} / \mathrm{w})$ with an acceptability rating of $\geq 7.25$

Flavor

The flavor of the product had acceptability scores from 6.70 to 7.50 which falls under "like moderately" to "like very much" in the 9-point Hedonic scale. The panelists described the flavor as having a "slightly pronounced ginger flavor" to "moderately pronounced ginger flavor" (Table 3a).

Table 4 presents the summary of the parameter estimates. It revealed that varying the levels of ginger and sugar had a significant linear effect $(p<0.05)$ on flavor acceptability of the Sinaging. However, the interaction between ginger and sugar had no significant effect on flavor acceptability of the product. Figure 3 shows a trend of an increase in ginger level corresponding to a decrease in flavor acceptability. This trend of decreasing acceptability was more pronounced at lower levels of sugar. However, at high levels of sugar, the flavor acceptability was more or less the same at any range of ginger. This result could be due to the essential oil present in ginger which contains $1-2 \%$ that imparts the unique flavor (Sasidharan and Menon 2010) and which means adding ginger extract enhances flavor acceptability.

The ginger flavor is a combination of pungent taste and aroma and is one of the major determinants for consumer acceptance (Pang et al 2017), thus, if added to Sinaging at a high level, ginger would tend to decrease its acceptability. The essential oil is characterized by a high percentage of sesquiterpenes, monoterpenes, and aliphatic compounds (Sharma et al 2016).

\section{Texture}

The mean acceptability scores for texture of the product ranged from 7.13 to 7.67 which falls under "like moderately" to "like very much" in the 9-point Hedonic scale. It was described by the panelists as 'slightly soft and moist' to 'moderately soft and moist' (Table $3 \mathrm{~b}$ ). The highest texture acceptability score among 
treatments was treatment 7 with the highest level of calamay sugar which was $30 \%$ and the lowest $2 \%$ ginger level, and with a mean acceptability rating of 7.67 . On the other hand, treatment 5 with $4 \%$ calamay sugar and $25 \%$ ginger had the lowest texture acceptability rating of 7.13. This corresponds to the contour plots in Figure 4. However, the parameter estimates presented in Table 4 shows that there is no significant difference in texture acceptability among treatments. This means increasing or decreasing the levels of sugar and ginger did not significantly affect the texture acceptability of the Sinaging.

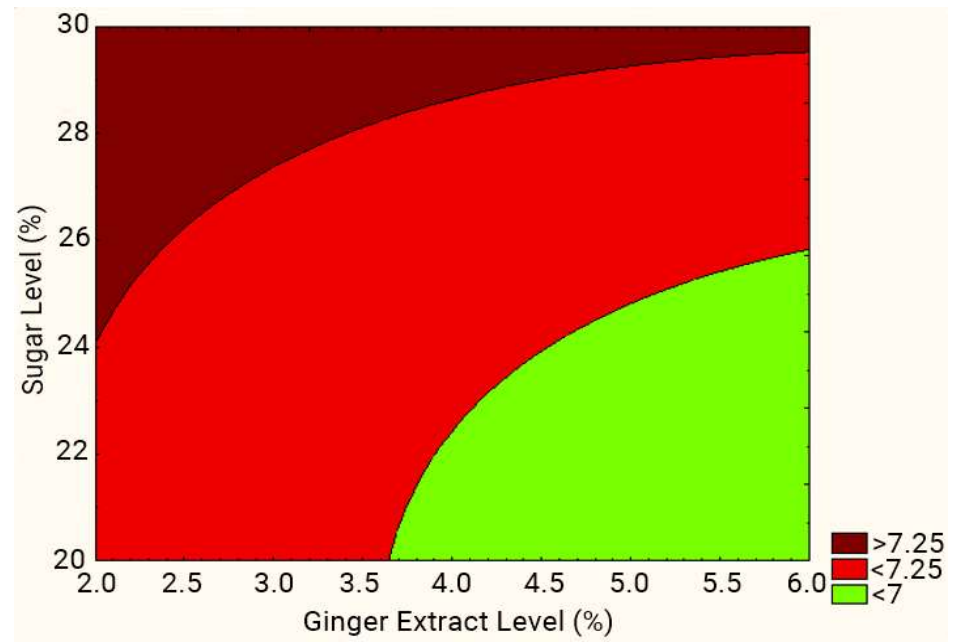

Figure 3. Contour plot of the flavor acceptability with varying levels of sugar $(\% \mathrm{w} / \mathrm{w})$ and ginger extract $(\% \mathrm{w} / \mathrm{w})$ with an acceptability rating of $\geq 7.25$

Taste

The taste description of the different treatments ranged from 'slightly sweet' to 'very sweet.' The results revealed that its acceptability score ranged from 6.89 to 7.50 which is equivalent to 'like slightly' to 'like moderately' in the 9-point Hedonic scale. The product had an overall response mean of 7.19 which falls under "like moderately" (Table 3b). The parameter estimates (Table 4) show that the individual variables had a positive linear significant effect on the taste acceptability $(p<0.05)$. This means that increasing both the calamay sugar and ginger levels would correspond to a significant increase on the product's taste acceptability as what is likewise shown in Figure 5. The contour plot of the taste acceptability (Figure 5) indicates that when the sugar was at low level, there was a corresponding low acceptability in taste. The same trend can be noted when the ginger was set at low level. 


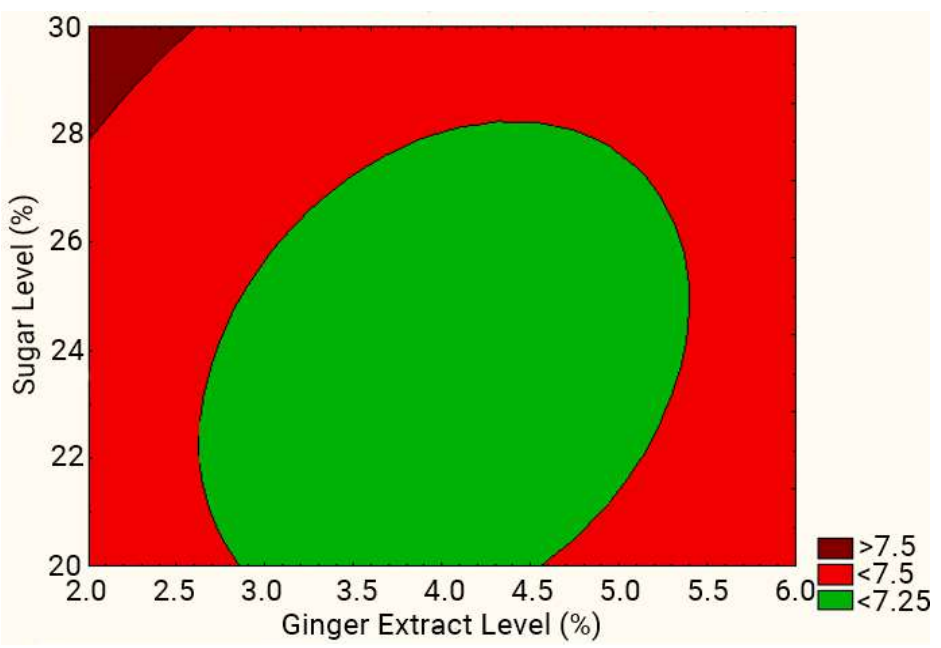

Figure 4. Contour plot of the texture acceptability with varying levels of sugar $(\% \mathrm{w} / \mathrm{w})$ and ginger extract $(\% \mathrm{w} / \mathrm{w})$ with an acceptability rating of $\geq 7.25$

Table 3b. Quality description and mean acceptability ratings of texture, taste, aftertaste and general acceptability of Sinaging as affected by different levels of ginger extract (GL) and sugar level (SL)

\begin{tabular}{|c|c|c|c|c|c|c|c|c|c|c|}
\hline \multirow{2}{*}{ Run } & \multirow{2}{*}{$\frac{\mathrm{GL}}{\%}$} & \multirow{2}{*}{$\frac{S L}{\%}$} & \multicolumn{2}{|c|}{ Texture } & \multicolumn{2}{|r|}{ Taste } & \multicolumn{2}{|c|}{ Aftertaste } & \multicolumn{2}{|c|}{$\begin{array}{c}\text { General } \\
\text { Acceptability }\end{array}$} \\
\hline & & & $\begin{array}{c}\text { Accept } \\
\text { ability }\end{array}$ & $\begin{array}{l}\text { Descri } \\
\text { ption }\end{array}$ & $\begin{array}{c}\text { Accept } \\
\text { ability }\end{array}$ & $\begin{array}{l}\text { Descrip } \\
\text { tion }\end{array}$ & $\begin{array}{c}\text { Accept } \\
\text { ability }\end{array}$ & $\begin{array}{l}\text { Descri } \\
\text { ption }\end{array}$ & $\begin{array}{c}\text { Accept } \\
\text { ability }\end{array}$ & $\begin{array}{l}\text { Descrip } \\
\text { tion }\end{array}$ \\
\hline 1 & 2 & 20 & 7.30 & $\begin{array}{c}\text { slightly } \\
\text { soft and } \\
\text { moist }\end{array}$ & 6.80 & $\begin{array}{l}\text { slightly } \\
\text { sweet }\end{array}$ & 7.13 & $\begin{array}{c}\text { slightly } \\
\text { perceptible }\end{array}$ & 6.97 & $\begin{array}{c}\text { Like } \\
\text { moderately }\end{array}$ \\
\hline 2 & 4 & 20 & 7.33 & $\begin{array}{l}\text { slightly } \\
\text { soft and } \\
\text { moist }\end{array}$ & 7.07 & $\begin{array}{l}\text { slightly } \\
\text { sweet }\end{array}$ & 7.17 & $\begin{array}{c}\text { slightly } \\
\text { perceptible }\end{array}$ & 6.90 & $\begin{array}{c}\text { like } \\
\text { moderately }\end{array}$ \\
\hline 3 & 6 & 20 & 7.40 & $\begin{array}{c}\text { moderatel } \\
\text { y soft and } \\
\text { moist }\end{array}$ & 7.07 & $\begin{array}{c}\text { very } \\
\text { sweet }\end{array}$ & 6.83 & $\begin{array}{c}\text { slightly } \\
\text { perceptible }\end{array}$ & 6.77 & $\begin{array}{c}\text { like } \\
\text { moderately }\end{array}$ \\
\hline 4 & 2 & 25 & 7.40 & $\begin{array}{c}\text { moderatel } \\
\text { y soft and } \\
\text { moist }\end{array}$ & 7.17 & $\begin{array}{l}\text { slightly } \\
\text { sweet }\end{array}$ & 7.47 & $\begin{array}{c}\text { slightly } \\
\text { perceptible } \\
\text { aftertaste }\end{array}$ & 7.37 & $\begin{array}{c}\text { like } \\
\text { moderately }\end{array}$ \\
\hline 5 & 4 & 25 & 7.13 & $\begin{array}{c}\text { moderatel } \\
\text { y soft and } \\
\text { moist }\end{array}$ & 7.17 & $\begin{array}{c}\text { moderately } \\
\text { sweet }\end{array}$ & 6.97 & $\begin{array}{c}\text { slightly } \\
\text { perceptible } \\
\text { aftertaste }\end{array}$ & 7.27 & $\begin{array}{c}\text { like } \\
\text { moderately }\end{array}$ \\
\hline 6 & 6 & 25 & 7.37 & $\begin{array}{c}\text { moderatel } \\
\text { y soft and } \\
\text { moist }\end{array}$ & 7.30 & $\begin{array}{c}\text { moderate } \\
\text { ly sweet }\end{array}$ & 7.27 & $\begin{array}{c}\text { slightly } \\
\text { perceptible } \\
\text { aftertaste }\end{array}$ & 7.23 & $\begin{array}{c}\text { like } \\
\text { moderately }\end{array}$ \\
\hline 7 & 2 & 30 & 7.67 & $\begin{array}{c}\text { moderatel } \\
\text { y soft and } \\
\text { moist }\end{array}$ & 7.50 & $\begin{array}{c}\text { moderate } \\
\text { ly sweet }\end{array}$ & 7.43 & $\begin{array}{c}\text { slightly } \\
\text { perceptible } \\
\text { aftertaste }\end{array}$ & 7.60 & $\begin{array}{l}\text { like very } \\
\text { much }\end{array}$ \\
\hline
\end{tabular}


Effect of ginger extract and sugar level

Table 3b continued

\begin{tabular}{|c|c|c|c|c|c|c|c|c|c|c|}
\hline \multirow{2}{*}{ Run } & \multirow{2}{*}{$\frac{\mathrm{GL}}{\%}$} & \multirow{2}{*}{$\begin{array}{l}\mathrm{SL} \\
\%\end{array}$} & \multicolumn{2}{|c|}{ Texture } & \multicolumn{2}{|r|}{ Taste } & \multicolumn{2}{|c|}{ Aftertaste } & \multicolumn{2}{|c|}{$\begin{array}{c}\text { General } \\
\text { Acceptability }\end{array}$} \\
\hline & & & $\begin{array}{c}\text { Accept } \\
\text { ability }\end{array}$ & $\begin{array}{l}\text { Descri } \\
\text { ption }\end{array}$ & $\begin{array}{l}\text { Accept } \\
\text { ability }\end{array}$ & $\begin{array}{l}\text { Descrip } \\
\text { tion }\end{array}$ & $\begin{array}{l}\text { Accept } \\
\text { ability }\end{array}$ & $\begin{array}{l}\text { Descri } \\
\text { ption }\end{array}$ & $\begin{array}{c}\text { Accept } \\
\text { ability }\end{array}$ & $\begin{array}{l}\text { Descrip } \\
\text { tion }\end{array}$ \\
\hline 8 & 4 & 30 & 7.27 & $\begin{array}{c}\text { slightly } \\
\text { soft and } \\
\text { moist }\end{array}$ & 7.37 & $\begin{array}{c}\text { moderate } \\
\text { ly sweet }\end{array}$ & 7.27 & $\begin{array}{c}\text { slightly } \\
\text { perceptible } \\
\text { aftertaste }\end{array}$ & 7.10 & $\begin{array}{c}\text { like } \\
\text { moderately }\end{array}$ \\
\hline 9 & 6 & 30 & 7.43 & $\begin{array}{l}\text { slightly } \\
\text { soft and } \\
\text { moist }\end{array}$ & 7.27 & $\begin{array}{l}\text { slightly } \\
\text { sweet }\end{array}$ & 7.07 & $\begin{array}{c}\text { slightly } \\
\text { perceptible } \\
\text { aftertaste }\end{array}$ & 7.07 & $\begin{array}{c}\text { like } \\
\text { moderately }\end{array}$ \\
\hline \multicolumn{2}{|c|}{ Mean } & & 7.37 & & 7.19 & & 7.18 & & 7.14 & $\begin{array}{c}\text { like } \\
\text { moderately }\end{array}$ \\
\hline
\end{tabular}

Legend: GL - Ginger Level, SL - Sugar Level

$\mathrm{N}=30$ panelists; Range of scores: 9-like extremely;8-like very much;7- like moderately;6-like slightly;5-neither like nor dislike,4- dislike slightly;3-dislike moderately;2-dislike very much;1-dislike extreme

Table 4. Summary of parameter estimates for the response of sensory acceptability of all the sensory attributes of Sinaging

\begin{tabular}{llllllll}
\hline Parameter & Color & Aroma & Flavor & Texture & Taste & $\begin{array}{c}\text { After } \\
\text { Taste }\end{array}$ & $\begin{array}{c}\text { General } \\
\text { Accepta } \\
\text { bility }\end{array}$ \\
\hline Intercept & $2.80^{\star}$ & $7.33^{\star}$ & $8.88^{\star}$ & $9.36^{\star}$ & $4.02^{\star}$ & $4.97^{\star}$ & $0.50^{\star}$ \\
Ginger & $0.45^{\text {ns }}$ & $-0.16^{\text {ns }}$ & $-0.32^{\star}$ & $-0.17^{\text {ns }}$ & $0.36^{\star}$ & $-0.16^{\text {ns }}$ & $-0.02^{\star}$ \\
Sugar & $0.27^{\text {ns }}$ & $0.00^{\text {ns }}$ & $-0.12^{\star}$ & $-0.16^{\text {ns }}$ & $0.16^{\star}$ & $0.19^{\text {ns }}$ & $0.52^{\star}$ \\
ginger*ginger & $-0.02^{\text {ns }}$ & $0.00^{\text {ns }}$ & $0.01^{\text {ns }}$ & $0.05^{\text {ns }}$ & $0.00^{\text {ns }}$ & $0.02^{\text {ns }}$ & $0.02^{\text {ns }}$ \\
sugar*ginger & $-0.01^{\text {ns }}$ & $0.00^{\text {ns }}$ & $0.01^{\text {ns }}$ & $-0.01^{\text {ns }}$ & $-0.01^{\text {ns }}$ & $0.00^{\text {ns }}$ & $-0.01^{\text {ns }}$ \\
sugar ${ }^{\star}$ sugar & $0.00^{\text {ns }}$ & $0.00^{\text {ns }}$ & $0.00^{\text {ns }}$ & $0.00^{\text {ns }}$ & $0.00^{\text {ns }}$ & $0.00^{\text {ns }}$ & $-0.01^{\text {ns }}$ \\
\hline
\end{tabular}

* =significant at $5 \% \quad$ **=significant at $1 \% \quad$ ns $=$ not significant

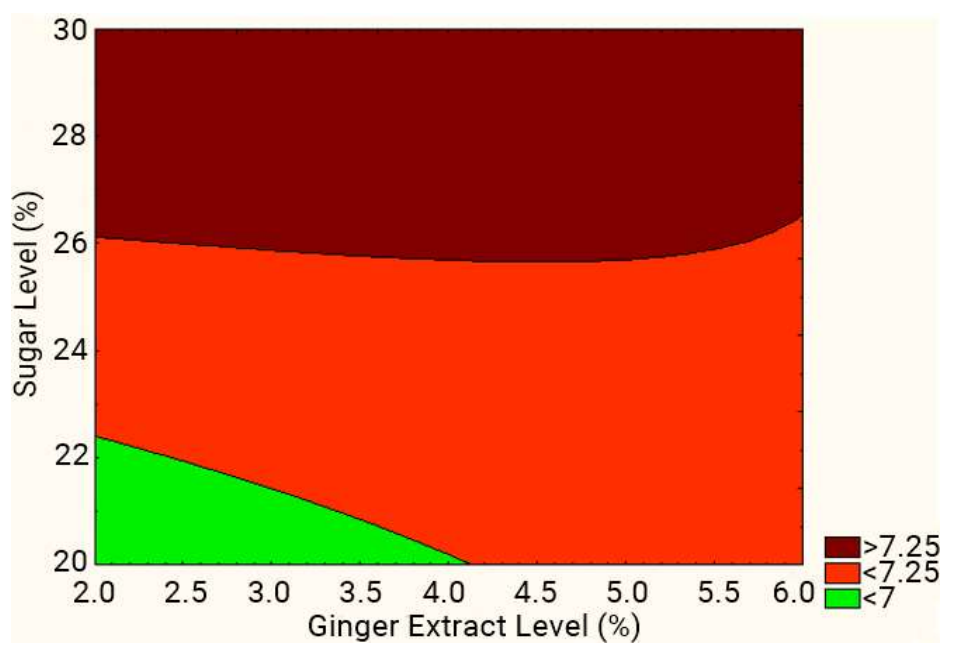

Figure 5. Contour plot of the taste acceptability with varying levels of sugar $(\% \mathrm{w} / \mathrm{w})$ and ginger extract $(\% \mathrm{w} / \mathrm{w})$ and ginger extract with an acceptability rating of $\geq 7.25$ 


\section{Aftertaste}

The aftertaste is another parameter that needs to be considered in the sensory attributes. The panelists evaluated based on their perception on the pungent aftertaste of the ginger. The response mean for aftertaste acceptability was 7.18. This falls under 'like moderately' category on the 9-point Hedonic scale, and the different product treatments were described as having a 'slightly perceptible aftertaste' (Table 3b). Figure 6 shows that the aftertaste acceptability decreased when the level of ginger extract increased, while an increase in sugar resulted in an increase in the aftertaste acceptability. However, this result was not significant based from the parameter estimates (Table 4). But it can still be noted that the highest acceptability rating (7.43) was observed at the highest level $(30 \%)$ of sugar. The presence of sugar could have counteracted with the distinct pungent taste of ginger.

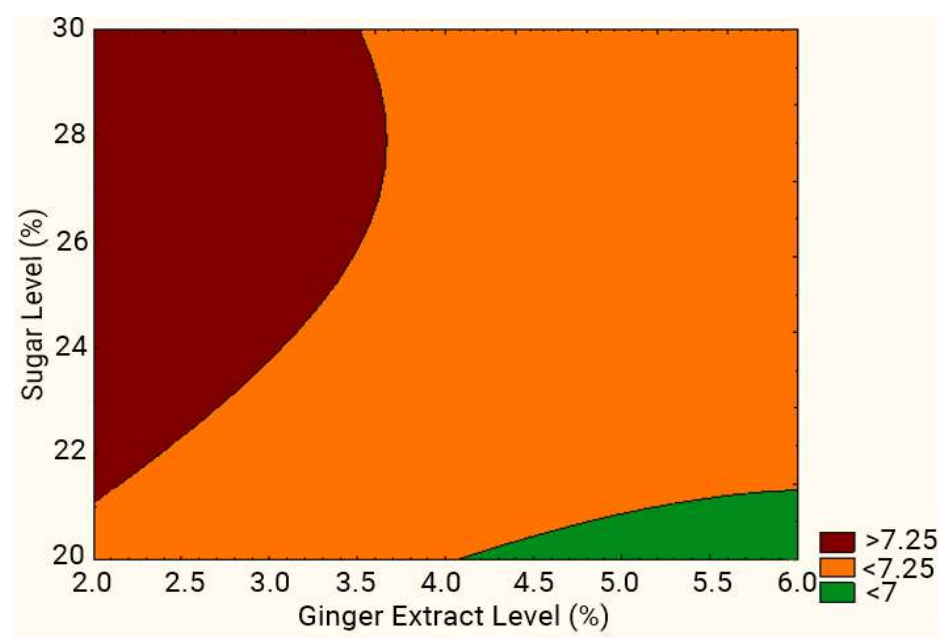

Figure 6 . Contour plot of the aftertaste acceptability with varying levels of sugar $(\% \mathrm{w} / \mathrm{w})$ and ginger extract $(\% \mathrm{w} / \mathrm{w})$ and ginger extract with an acceptability rating of $\geq 7.25$.

\section{General Acceptability}

Table $3 \mathrm{~b}$ shows the summary of the results of the quality description and mean acceptability of the Sinaging. The general acceptability of the product was described by the panelist as 'like moderately' to 'like very much' with a range of mean acceptability rating from 6.77 to 7.60 in the 9-point Hedonic Scale.

The general acceptability of Sinaging decreased with increasing levels of ginger. On the other hand, the general acceptability of Sinaging increased when there was a corresponding increase in sugar level as reflected in the result of regression analysis (Table 4). The highest acceptability rating was 7.18 which corresponds to 'like moderately' produced from $2 \%$ ginger and $30 \%$ sugar. On the other hand, the treatment with lowest acceptability of 6.77 was produced with $6 \%$ ginger and $20 \%$ sugar (Table $3 \mathrm{~b}$ ). This trend is likewise shown in contour plot in Figure 7. 
Effect of ginger extract and sugar level

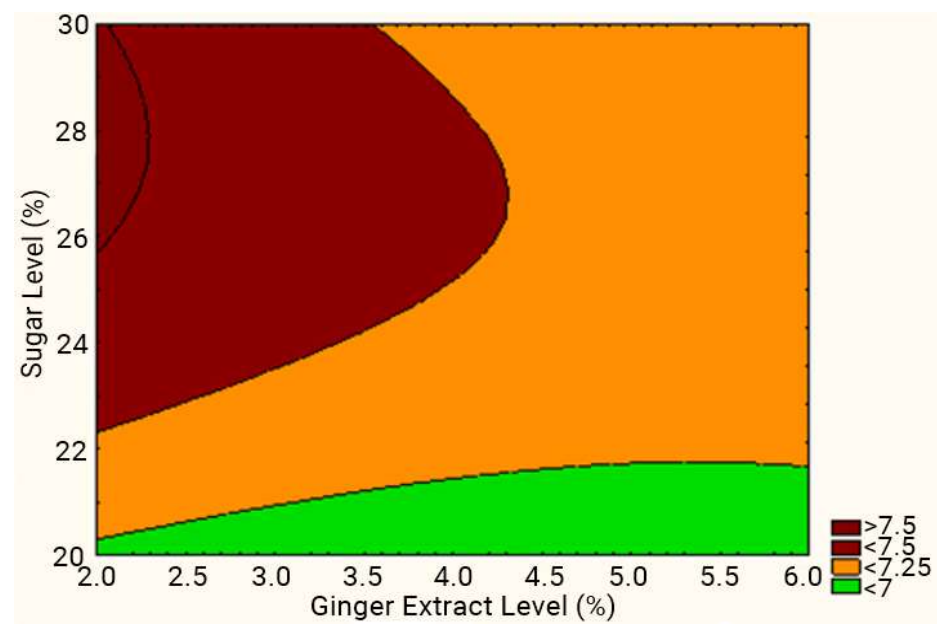

Figure 7. Contour plot of the general acceptability with varying levels of sugar $(\% \mathrm{w} / \mathrm{w})$ and ginger extract $(\% \mathrm{w} / \mathrm{w})$ and ginger extract with an acceptability rating of $\geq 7.25$.

\section{Optimized Region in the Experiment}

A minimum acceptability rating of $\geq 7.25$ was set as the cut-off score for the acceptability of the three parameters found to have significant effects on the product. The point within the region indicates optimized combinations of the processing variables. The only parameter enclosing the region which is significantly affected by ginger and sugar are flavor and general acceptability while the taste and production cost are way out of the optimum region. Noncontributing parameters like color, texture, aroma, and aftertaste were neglected to give more room for the incorporation of ginger. Figure 9 shows that the optimum combination in producing the Sinaging is at $28.75 \%$ calamay sugar and $4.05 \%$ ginger.

The model equation used in the calculation of the predicted values is shown below.

$$
\begin{array}{ll}
\text { Parameter } & \multicolumn{1}{c}{\text { Model Equation }} \\
\text { Color } & =2.801852+0.448611 \mathrm{x}+0.271111 \mathrm{y}-0.01528 \mathrm{x} 2-0.0125 \mathrm{xy} \\
\text { acceptability } & -0.00378 \mathrm{y} 2 \\
& =7.32963-0.16389 \mathrm{x}-0.00111 \mathrm{y}+0.001389 \mathrm{x} 2+0.003333 \mathrm{xy} \\
\text { Aroma } & +0.000222 \mathrm{y} 2 \\
\text { acceptability } & =8.875926-0.32361 \mathrm{x}-0.11555 \mathrm{y}+0.006944 \mathrm{x} 2+0.0075 \mathrm{xy} \\
\text { Flavor } & +0.002444 \mathrm{y} 2
\end{array}
$$


Parameter

Texture acceptability

Taste

acceptability

Aftertaste acceptability

General acceptability
Model Equation

$$
=9.35555--0.17222 x--0.15556 y+0.045833 x 2-0.00833 x y
$$$$
+0.004 \text { y2 }
$$$$
=4.016667+0.359722 x+0.156667 y-0.00417 x 2-0.0125 x y
$$$$
-0.00133 \text { y2 }
$$$$
=4.966667-0.16389 x+0.194444 y+0.016667 x 2-0.00167 x y
$$$$
-0.00333 \text { y2 }
$$

$$
\begin{aligned}
= & 0.5037-0.01944 x+0.515556 y+0.019444 x 2-0.00833 x y \\
& -0.00889 y 2
\end{aligned}
$$

where:

$\mathrm{x}=$ levels of ginger, $\%$

$y=$ levels of sugar, $\%$

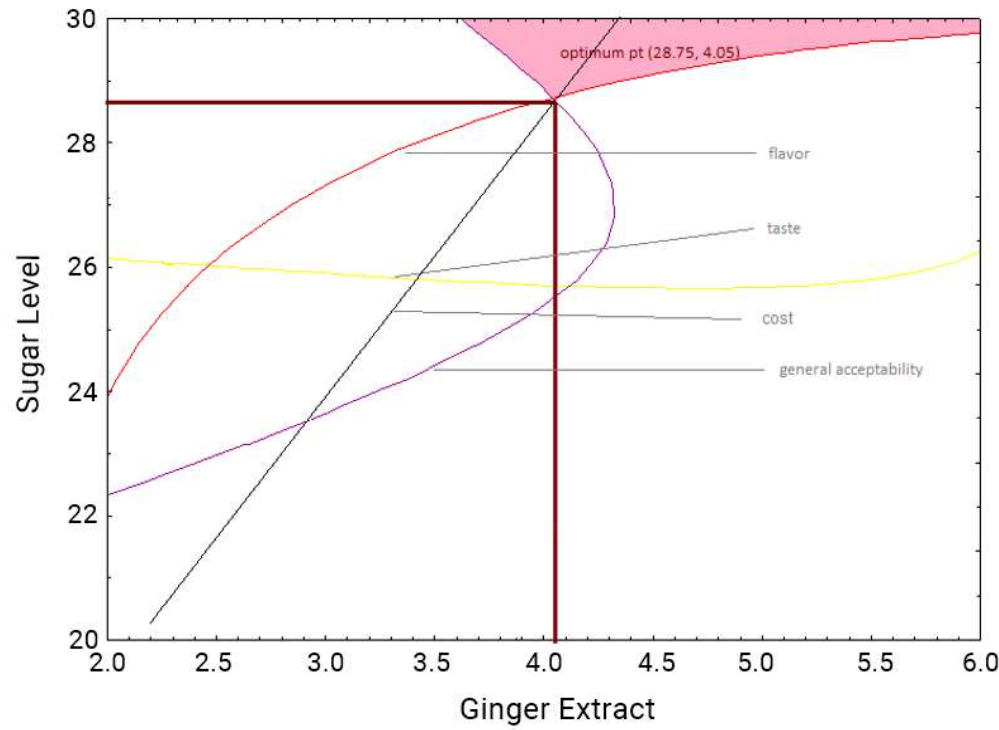

Figure 9. Optimum region (shaded) for Sinaging generated by superimposing contour plots of sensory acceptability set at $\geq 7.25$

\section{Verification}

Table 5 summarizes the t-test results between the samples within and outside the optimum region. Statistical analysis showed that there was a significant difference in the acceptability between the two samples in terms of flavor, texture, taste, aftertaste and general acceptability. No significant difference was noted in terms of its color and aroma. The results of the optimum formulation were further analyzed and the results were statistically compared to the predicted values of the mathematical model. The predicted 
response values and the actual obtained response values for the optimized formulation were found to be not statistically different at the $95 \%$ confidence level, as summarized in Table 6 . This indicates that the model can well predict the values of the sensory attributes. The percentage error was also calculated to measure the deviations of the observed values from the predicted values of the responses. As mentioned by Bandalan (2020), generally, a percentage error of $10 \%$ or less is considered acceptable for most analyses. Thus, the models used for calculating the predicted values are accurate.

Table 5. Mean acceptability and the t-test result of the samples from inside and outside the optimum region

\begin{tabular}{lccc}
\hline Sensory Attribute & Optimum & Outside & Remarks \\
\hline Color & 7.44 & 7.00 & $\mathrm{~ns}$ \\
Aroma & 7.34 & 6.91 & $\mathrm{~ns}$ \\
Flavor & 7.38 & 5.41 & $\star \star$ \\
Texture & 7.53 & 5.19 & $\star \star$ \\
taste & 7.53 & 5.31 & $\star \star$ \\
Aftertaste & 7.47 & 5.56 & $\star$ \\
GenAcc & $7.31 \mathrm{a}$ & $5.56 \mathrm{~b}$ & $\star \star$ \\
\hline ** significant at $p<0.001$ & *significant at $p<0.05$ & ns not significant
\end{tabular}

Table 6. Results of the verification tests for the proposed model equation of the optimum formulation at $95 \%$ confidence

\begin{tabular}{lcccc}
\hline Attribute & Observed Values & Predicted Value & Percent Error & Percent Difference \\
\hline Color & 7.44 & 7.58 & -1.93 & -1.95 \\
Aroma & 7.34 & 7.23 & 1.60 & 1.58 \\
Flavor & 7.38 & 7.25 & 1.72 & 1.70 \\
Texture & 7.53 & 7.27 & 3.54 & 3.48 \\
Taste & 7.53 & 7.35 & 2.44 & 2.41 \\
Aftertaste & 7.47 & 7.22 & 3.48 & 3.42 \\
General & 7.31 & 7.25 & 0.88 & 0.88 \\
Acceptability & & & & \\
\hline
\end{tabular}

\section{Production Cost}

The production cost of different treatments is summarized in Table 5. A breakeven price ranged from PHP8.09 to PHP8.96 per $75 \mathrm{~g}$ of Sinaging. An increasing trend in the production cost of Sinaging can be observed with a corresponding increase in the levels of ginger extract (Figure 10). The production cost was a limiting factor when superimposed with other parameters during optimization. The cost in producing the optimum combination was PHP8.34. 
Table 5. Summary of the production cost of the different treatments of Sinaging

\begin{tabular}{ccccccc}
\hline Run & $\begin{array}{c}\text { Ginger } \\
\text { Extract Level } \\
(\% \mathrm{w} / \mathrm{w})\end{array}$ & $\begin{array}{c}\text { Sugar Level } \\
(\% \mathrm{w} / \mathrm{w})\end{array}$ & $\begin{array}{c}\text { Cost } \\
(\mathrm{PHP})\end{array}$ & $\begin{array}{c}\text { Total } \\
\text { Weight } \\
(\mathrm{g})\end{array}$ & $\begin{array}{c}\text { Number } \\
\text { of Pieces } \\
(75 \mathrm{~g} / \mathrm{pc})\end{array}$ & $\begin{array}{c}\text { Breakeven } \\
\text { Price/pc }\end{array}$ \\
\hline 1 & 2 & 20 & 140.32 & 1273.1 & 17 & 8.27 \\
2 & 4 & 20 & 148.76 & 1294.2 & 17 & 8.62 \\
3 & 6 & 20 & 157.20 & 1315.3 & 18 & 8.96 \\
4 & 2 & 25 & 144.56 & 1326.1 & 18 & 8.18 \\
5 & 4 & 25 & 153.00 & 1347.2 & 18 & 8.52 \\
6 & 6 & 25 & 161.44 & 1368.3 & 18 & 8.85 \\
7 & 2 & 30 & 148.80 & 1379.1 & 18 & 8.09 \\
8 & 4 & 30 & 157.24 & 1400.2 & 19 & 8.42 \\
9 & 6 & 30 & 165.68 & 1421.3 & 19 & 8.74 \\
optimum & 4.05 & 28.75 & & & & 8.34 \\
\hline
\end{tabular}

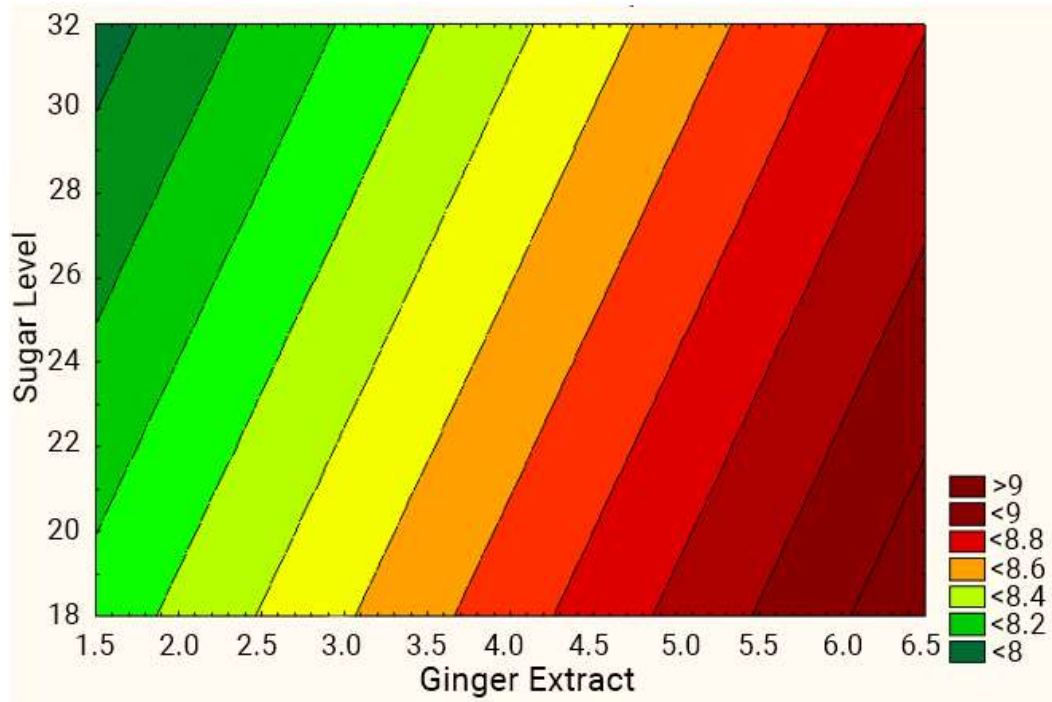

Figure 10. Contour plot of the production cost of Sinaging as affected by varying levels of sugar (\%w/w) and ginger extract (\%w/w)

\section{CONCLUSION}

The varying levels of sugar and ginger extract significantly affected linearly the flavor, taste, and general acceptability of Sinaging. No significant effect was observed due to its color, aroma, texture, and aftertaste acceptability. The 
optimum formulation in Sinaging production was found to be at $4.05 \%$ and $28.75 \%$ ginger extract and sugar, respectively. The cost in producing the optimum was 8.34 pesos per 75 grams.

\section{REFERENCES}

Asikin Y, Hirose N, Tamaki H, Ito S, Oku H \& Wada K. 2016. Effects of different drying-solidification processes on physical properties, volatile fraction, and antioxidant activity of non-centrifugal cane brown sugar. LWT-Food Science and Technology 66:340-347

Bandalan E. 2020. Optimization, characterization, and processing potential of spray-dried buffalo milk (Unpublished PhD dissertation). University of the Philippines Los Baños, Laguna

Chen IN, Chang CC, Ng CC, Wang CY, Shyu YT \& Chang TL. 2008. Antioxidant and antimicrobial activity of zingiberaceous plants in Taiwan. Plants Foods for Human Nutrition 63(1):15-20

Cochran WG and Cox GN. 1957. Experimental design (2nd edn). John Wiley and Sons, Inc. New York

Galant AL, Kaufman RC \& Wilson JD. 2015. Glucose: detection and analysis. Food Chemistry 188:149-160

Islam K, Rowsni AA, Khan M \& Kabir S. 2014. Antimicrobial activity of ginger (Zingiber officinale) extracts against food-borne pathogenic bacteria. International Journal of Science, Environment 3(3):867-871

Parthasarathy VA, Chempakam B \& Zachariah TJ. 2008. Chemistry of spices, $\mathrm{CABI}$, London

Pagatpatan A, Morante T, Lagramada C \& Yodico C. 2017 Acceptability of Palawan sasema as a local delicacy. International Journal of Innovation and Research in Educational Sciences 4(1):2349-5219

Pang X, Cao J, Wang D, Qiu J \& Fanyu Kong F 2017. Identification of ginger (Zingiber officinale Roscoe) volatiles and localization of aroma-active constituents by Gc-Olfactometry. Journal of Agricultural and Food Chemistry 65(20):4140-414

Sasidharan I and Menon AN. 2010. Comparative chemical composition and antimicrobial activity fresh and dry ginger oils (Zingiber officinale Roscoe). International Journal of Current Pharmaceutical Research 2(4):40-43

Sharma P, Singh V \& Ali M. 2016. Chemical composition and antimicrobial activity of fresh rhizome essential oil of Zingiber officinale Roscoe. Pharmacognosy Journal 8(3):185-190

Sutherland JA. 2017. Introduction to tropical agriculture, McGraw-Hill Education, Australia 